Acta Horticulturae et Regiotecturae 2

Nitra, Slovaca Universitas Agriculturae Nitriae, 2017, pp. 44-48

\title{
THE EFFECT OF VARIETIES AND DEGREE OF RIPENESS TO VITAMIN C CONTENT IN TOMATO FRUITS
}

\author{
Magdaléna VALŠÍKOVÁ-FREY*, Patrik KOMÁR, Marián REHUŠ \\ Slovak University of Agriculture in Nitra, Slovak Republic
}

\begin{abstract}
Nine selected varieties of tomatoes were grown in field experiments in order to follow up changes in the content of vitamin $\mathrm{C}$, depending on the degree of the fruit ripeness. Vitamin C content of green fruit ranged from $6.74 \mathrm{mg}$ (Denár) to $10.23 \mathrm{mg}$ (Salus). The mean value for the varieties in the green state was $8.66 \mathrm{mg}^{1} 100 \mathrm{~g} \mathrm{~g}^{-1}$. The value of vitamin $\mathrm{C}$ in the semi-mature tomatoes ranged from $11.34 \mathrm{mg}$ (Denár) to $14.95 \mathrm{mg}$ (Darinka). The mean value for all varieties was $12.89 \mathrm{mg} .100 \mathrm{~g} \mathrm{~g}^{-1}$. The lowest content of vitamin C was found in consumer (red) ripening tomato varieties Šejk (16.03 mg), Denár (16.32 mg) and Zámčan (16.80 mg) and the highest content of vitamin C in varieties Salus $(19.43 \mathrm{mg})$ and Darinka $(19.26 \mathrm{mg})$. The mean value for the nine varieties was $17.70 \mathrm{mg} .100$ $\mathrm{g}^{-1}$. In the botanical (overripe) maturity, we recorded the highest vitamin C content in the variety Salus $\left(21.51 \mathrm{mg}^{1} 100 \mathrm{~g}^{-1}\right)$. The highest increase in vitamin C was also recorded at the variety Darinka, where we registered the content of $21.32 \mathrm{mg}^{100} \mathrm{~g}^{-1}$. The lowest vitamin C content in botanical ripeness was observed in the variety Zámčan $\left(19.44 \mathrm{mg} .100 \mathrm{~g}^{-1}\right)$. The average amount of vitamin C marked $20.26 \mathrm{~g} \mathrm{mg} \cdot 100^{-1}$. The results can be concluded that the level of vitamin $\mathrm{C}$ is increasing by the gradual ripening of the fruits.
\end{abstract}

Keywords: tomatoes; maturity stages; vitamin C

Tomato is one of the most frequent and most popular vegetables in the world (Dorais, Ehret, Papadopoulos, 2008). According to FAOSTAT statistics, the largest producers of tomatoes in the world are China, India, USA, and Turkey (FAOSTAT, 2014). The fruits of tomatoes are tasty, easily digestible; they are widely used in gastronomy and in the canning industry (Toor and Savage, 2004). As for their composition, tomatoes are valuable kinds of vegetables, like bell peppers. They contain precious minerals, vitamins and other bioactive components and antioxidants which help to prevent against many civilization diseases (Valšíková and Paulen 2013). In Slovakia, tomatoes are grown on the area of about 500 ha of arable land, where about 20,000 tons are produced annually. The total area of tomatoes (including gardens), occupies 2800 ha and produces the annual average of 50,000 tons. With this production, tomatoes are in second place after cabbage (Meravá et al., 2015; Rozborilová et al., 2016).

\section{Material and methods}

The field experiment was established in the botanical garden of the Slovak University of Agriculture in Nitra. For testing purposes, we used nine varieties of tomatoes (Table 1).

The results of soil analysis (2013-2014):

1. $\mathrm{N}_{\mathrm{an}}=13.3-14 \mathrm{mg} \cdot \mathrm{kg}^{-1}$ soil,

2. $P=120.5-118 \mathrm{mg}^{\mathrm{k}} \mathrm{kg}^{-1}$ soil,

3. $\mathrm{K}=525-235 \mathrm{mg} \cdot \mathrm{kg}^{-1}$ soil,
4. $\mathrm{Ca}=4,976-5,100 \mathrm{mg} \cdot \mathrm{kg}^{-1}$ soil,

5. $\mathrm{Mg}=576-548 \mathrm{~g}^{\mathrm{kg}} \mathrm{k}^{-1}$ soil,

6. $\mathrm{S}=45-50 \mathrm{mg} \cdot \mathrm{kg}^{-1}$ of soil,

7. humus content $=3.75-3.65 \%$,

8. $\mathrm{pH} / \mathrm{KCl}=6.96-7.00$.

The first fertilization during the vegetation period was performed in both years in mid-June. The LAD $27 \%$ in the amount of $200 \mathrm{~g}$ on the area $30 \mathrm{~m}^{2}$ was applied to soil. The NPK was applied at $200 \mathrm{~g}$ per trial plot of $30 \mathrm{~m}^{2}$ in mid-July.

Sowing was carried out on March 13, 2013 and March 17,2014 into seeding trays in lines. Transplanting was done on April 16, 2013 and April 15, 2014 into rooting containers with the plants space of $40 \times 40 \times 80 \mathrm{~mm}$. Growing transplants have not been chemically treated, but were fertilized by Harmavit with foliar sprays in the end of April. Ready transplants were planted into outside beds on May 16, 2013 and May 14, 2014.

Parameters of experiments:

- spacing of planting: $0.30 \times 0.60 \mathrm{~m}$,

- number of plants per a variety: 12,

- number of repetitions: 3 ,

- area per a variety: $2.52 \mathrm{~m}^{2}$,

- area of all varieties: $24 \mathrm{~m}^{2}$.

\section{Harvesting and analysis of fruits}

Dates of fruits harvesting: August 2, 2013 and August 5, 2014 in green maturity, August 14, 2013 and August 18, 
Table 1 Origins and properties of tomato varieties

\begin{tabular}{|c|c|c|c|}
\hline Variety & Origin & Fruit shape & Suitability \\
\hline Darinka F1 & Czechia, Semo a. s. & round & manual harvesting, consumption \\
\hline Denár & Czechia, Semo a. s. & pear-shaped to square & manual and mechanized harvesting, processing \\
\hline Diana & Czechia, Semo a. s. & round & manual harvesting, consumption \\
\hline Kecskeméti & Hungary & flat-round & manual harvesting, consumption \\
\hline Oranže & Czechia, Semo a. s. & flat-spherical & manual harvesting, consumption \\
\hline Paulína & Czechia, Semo a. s. & round & $\begin{array}{c}\text { manual and mechanized harvesting, consumption, } \\
\text { processing }\end{array}$ \\
\hline Salus & Czechia, Semo a. s. & oval or square & $\begin{array}{l}\text { manual and mechanized harvesting, consumption, } \\
\text { processing }\end{array}$ \\
\hline Šejk & Czechia, Semo a. s. & oval or square, intense red & manual and mechanized harvesting, processing \\
\hline Zámčan & Slovak Republic, Lestra s. r. o. & rectangular & mechanized harvesting, processing \\
\hline
\end{tabular}

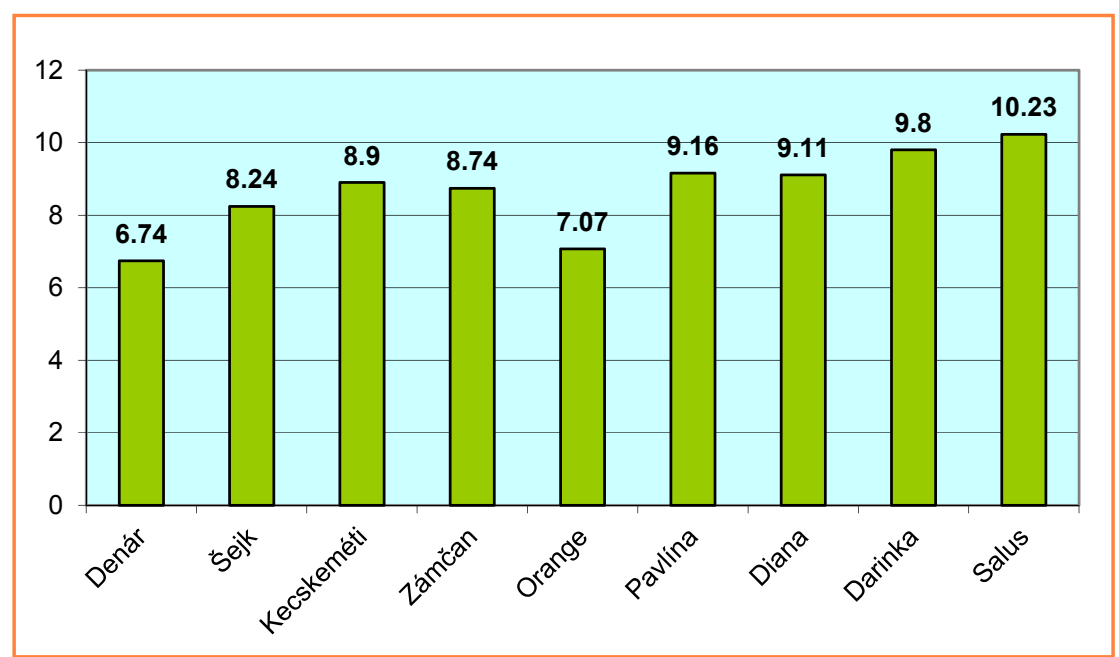

Figure 1 Mean content of vitamin C in green mature tomatoes in $\mathrm{mg} .100 \mathrm{~g} \mathrm{~g}^{-1}$

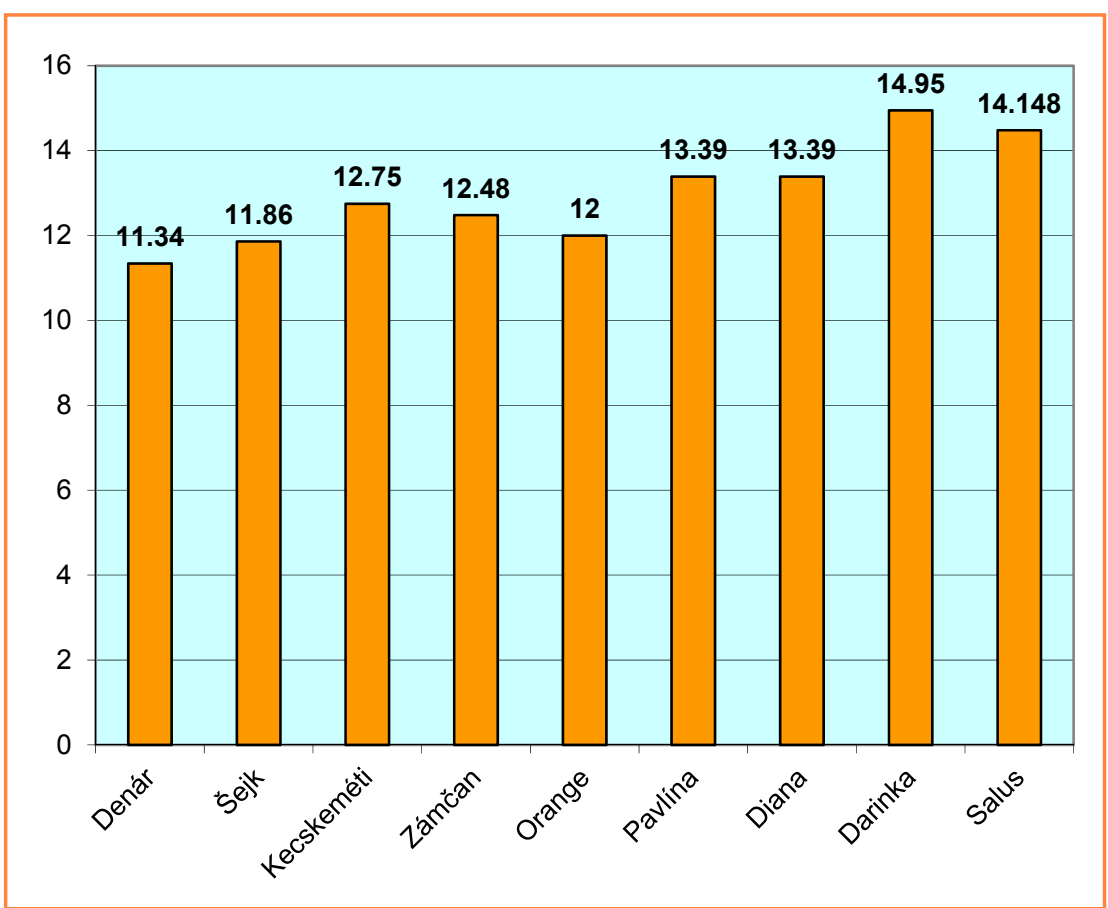

Figure 2 Mean content of vitamin C in semi-mature tomatoes in $\mathrm{mg} .100 \mathrm{~g}^{-1}$
2014 in semi-mature stage, August 22, 2013 and August 28, 2014 in consumer (red) maturity, September 9, 2013 and September 16, 2014 in botanical (overripe) maturity. The analysis of fresh tomato fruits was carried out in the laboratory at the Department of Vegetables Production of the Slovak University of Agriculture in Nitra. For determination of vitamin C content, the HPLC method with liquid chromatograph and UV detector was used (Stan et al., 2014).

\section{Statistical evaluation}

To establish the evidential differences in vitamin C, we used the program Statgraphics Centurion XVII (Stat Point Inc. USA). The results were evaluated by the analysis of variance (ANOVA) and the mean values were tested by the Tukey HSD test at the significance level of $95 \%$.

\section{Results and discussion}

\section{Evaluation of the vitamin C content} in green mature tomatoes

The samples were harvested in green fruit stage for determining the amount of vitamin C per $100 \mathrm{~g}$ of fresh material. The content of vitamin $C$ in the varieties ranged from $6.74 \mathrm{mg}$ (Denár) to $10.23 \mathrm{mg}$ (Salus). The mean value of all varieties was $8.66 \mathrm{mg} .100 \mathrm{~g} \mathrm{~g}^{-1}$. There was no significant difference between replicates. The mean value of the vitamin $C$ content for the two monitored years is shown in Figure 1. 


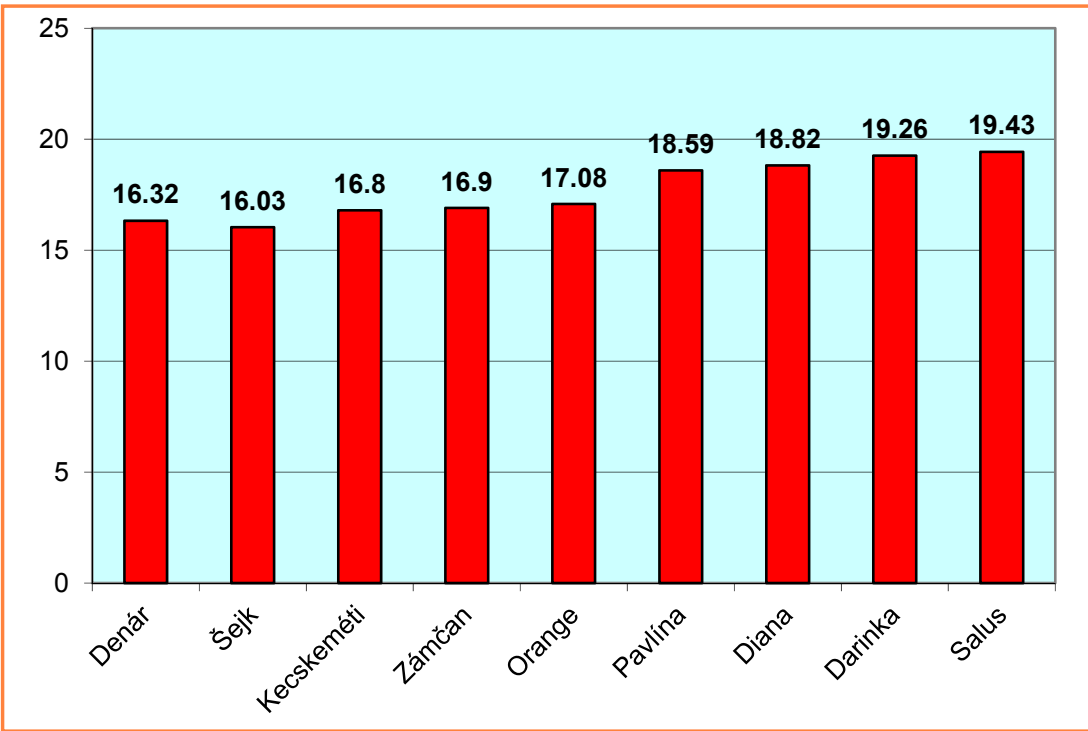

Figure 3 Mean content of vitamin C in consumer (red) maturity in mg. $100 \mathrm{~g} \mathrm{~g}^{-1}$

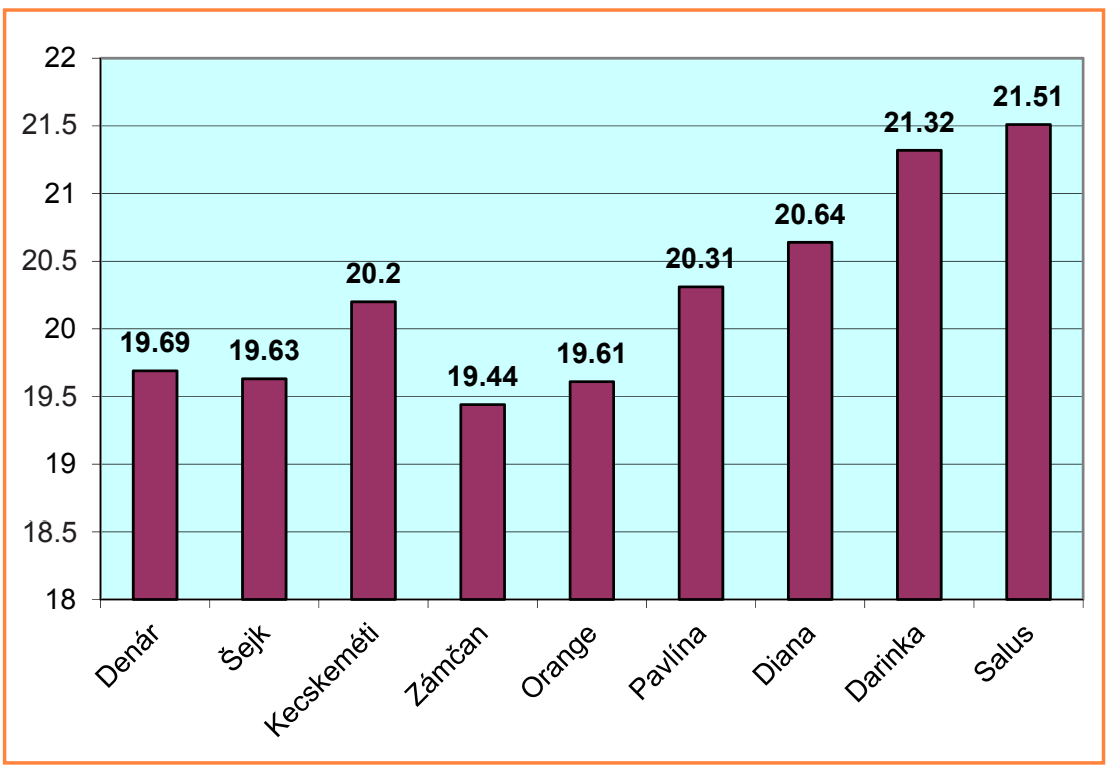

Figure 4 Mean content of vitamin C in botanical (red) maturity in $\mathrm{mg}^{1} 100 \mathrm{~g} \mathrm{~g}^{-1}$

\section{Evaluation of the vitamin C content tomatoes}

in semi-mature tomatoes

Semi-mature tomatoes are not suitable for consumption yet. The value of vitamin C ranged from $11.34 \mathrm{mg}$ (Denár) to $14.95 \mathrm{mg}$ (Darinka). The mean value of all varieties in the two years marked $12.89 \mathrm{mg}^{1} 100 \mathrm{~g}^{-1}$ (Figure 2). Compared to the values of green fruits, there was an increase in the amount of vitamin C.

\section{Evaluation of the vitamin C content in tomatoes of consumer (red) maturity}

The fruits were ripe and red-coloured, except of the variety Orange, which matures into orange colour. We found out that the lowest content of vitamin $C$ was recorded in the varieties Šejk (16.03 mg) and Denár (16.32 mg). The highest content of vitamin C (19.43 mg) was marked by the varieties Salus and Darinka with $19.26 \mathrm{mg}^{1} 100 \mathrm{~g}^{-1}$ (Figure 3 ). The mean value of all varieties for the two years was $17.70 \mathrm{mg}$.

\section{Evaluation of the vitamin C content in botanically mature (overripe) tomatoes}

The botanical (overripe) maturity of tomato fruits was reached in midSeptember. The fruits were mostly already softened but in good health with no signs of damage. We recorded the highest vitamin $C$ content of 21.51 mg.100 g $\mathrm{g}^{-1}$ at the variety Salus (Fig. 4), which is about $10.71 \%$ more than in the consumer (red) maturity and by $48.54 \%$ more than in the semi-mature

Table 2 Mean content of vitamin C in differently ripened tomatoes in $\mathrm{mg} 100 \mathrm{~g}^{-1}$

\begin{tabular}{|l|c|c|c|}
\hline Varieties & Green fruits & Semi-red fruits & Red fruits \\
\hline Denár & 6.74 & 11.34 & 16.32 \\
\hline Šjk & 8.24 & 11.86 & 16.03 \\
\hline Kecskeméti & 8.90 & 12,75 & 16.80 \\
\hline Zámčan & 8.74 & 12.48 & 16.90 \\
\hline Orange & 7.07 & 12.00 & 17.08 \\
\hline Paulína & 9.16 & 13.39 & 18.59 \\
\hline Diana & 9.11 & 13.39 & 18.82 \\
\hline Darinka & 9.80 & 14.95 & 19.61 \\
\hline Salus & 10.23 & 14.48 & 20.31 \\
\hline Average & 8.66 & 12.89 & 19.43 \\
\hline
\end{tabular}


fruits. We found $110.26 \%$ increase of the vitamin C content in the variety Salus compared to the situation in green maturity.

High increase of vitamin $C$ was recorded also at the variety Darinka, where we recorded the content of $21.32 \mathrm{mg} .100 \mathrm{~g}^{-1}$. It is by about $10.69 \%$ more than in the consumer (red) maturity and by $42.61 \%$ more than at the semi-maturity and by $117.55 \%$ more than at harvest in the green maturity.

The lowest level of vitamin C in botanical ripeness was found in the variety Zámčan (19.44 mg.100-1), which is by $15.03 \%$ more than in the consumer (red) maturity and by $55.76 \%$ more than in the semi-maturity. At this variety was in the botanical (overripe)

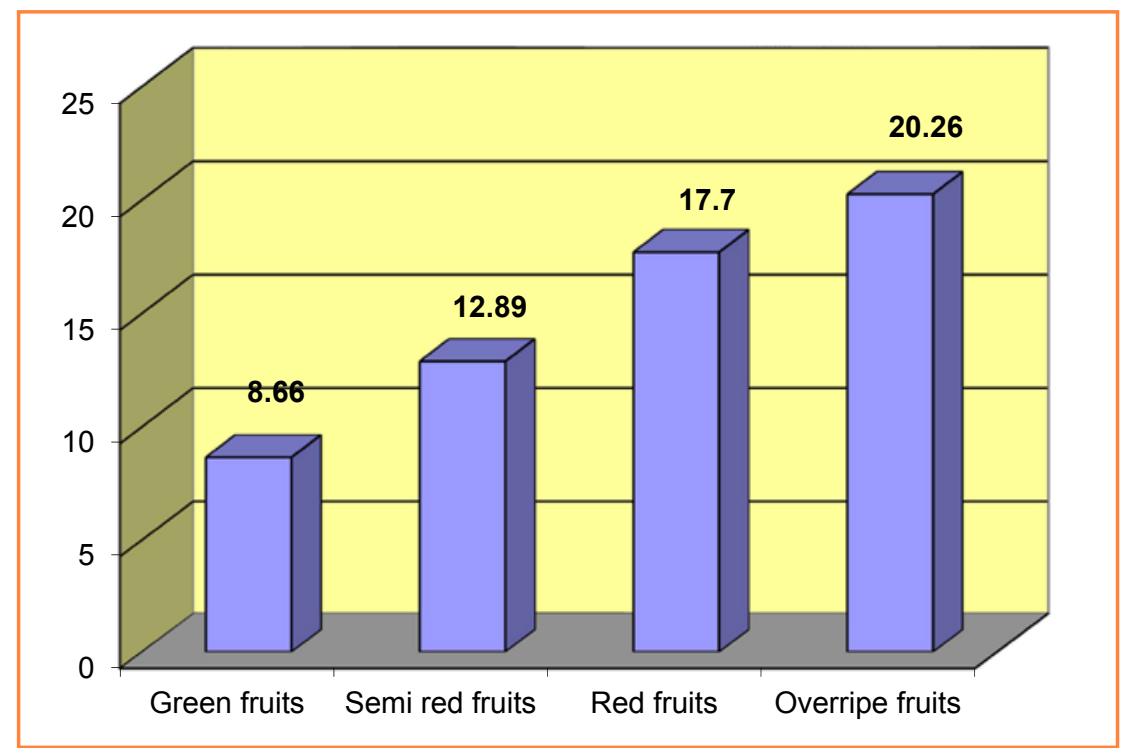

Figure 5 Mean content of vitamin C in differently ripened tomato fruits in mg. $100 \mathrm{~g}^{-1}$

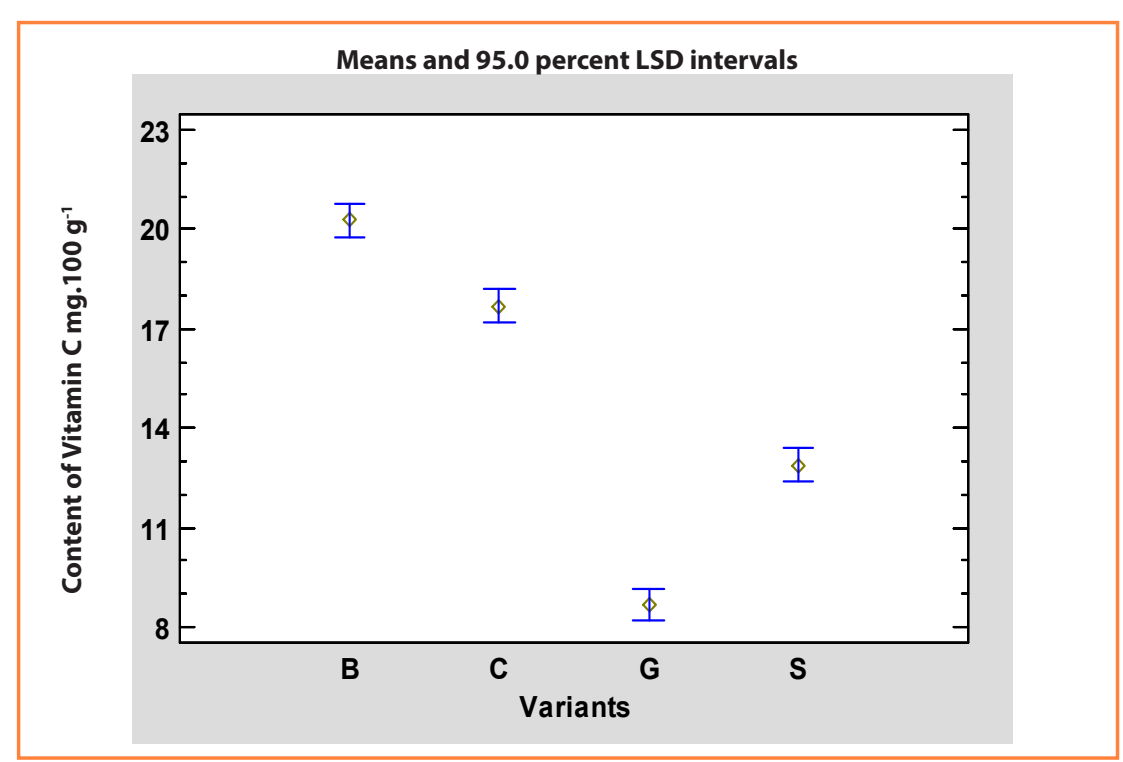

Figure 6 Tests for the vitamin $\mathrm{C}$ content in $\mathrm{mg} .100 \mathrm{~g} \mathrm{~g}^{-1}$ by variants

Table 3 Multiple range tests for the vitamin C content in $\mathrm{mg} .100 \mathrm{~g}^{-1}$ by years Method: 95.0 percent LSD

\begin{tabular}{|l|c|c|c|c|}
\hline Years & Count & LS Mean & LS Sigma & Homogeneous Groups \\
\hline $\mathbf{2 0 1 3}$ & 108 & 13.0842 & 0.463313 & X \\
\hline $\mathbf{2 0 1 4}$ & 108 & 16.6718 & 0.463313 & $\mathrm{X}$ \\
\hline
\end{tabular}

maturity more vitamin $\mathrm{C}$ about $122.42 \%$ compared to the result of the harvesting in the green maturity. The average amount of vitamin $\mathrm{C}$ marked $20.26 \mathrm{~g} \mathrm{mg} 100^{-1}$. The average value of vitamin $C$ in different ripened tomato varieties and in two years is shown in Table 2. Fig. 5 shows differences in the vitamin $C$ content by tomato fruit maturity.

From the results we can conclude that the levels of vitamin Cincrease with the gradual ripening of fruits, which is confirmed by works of other authors such as Kader (1999) and Rahman et al. (2016). Valšíková et al. (1996) report that the average content of vitamin $C$ in tomato ripe fruits is in the range 20-80 mg. Similar values are shown by Kopec (1998), namely 20-50 mg. Uher et al. (2009) give lower values, $22.4 \mathrm{~g}$ of $\mathrm{mg} \cdot 100^{-1}$. Similar results are indicated by Kopec (2010). We are closer to these values in the botanical maturity as our measured values ranged from 19.44 to $21.51 \mathrm{mg} .100 \mathrm{~g}^{-1}$. Jedlička (2012) argues that tomato is a good source of vitamin C as $100 \mathrm{~g}$ of tomatoes provide $21 \%$ ( $13 \mathrm{~g}$ ) of the recommended daily allowance (RDA). That results are in compliance with our results, as during the transition of maturity we obtained the values ranging from 11.6 to $15.8 \mathrm{mg}$. In our experiment, it was found out that the amount of vitamin $\mathrm{C}$ in the consumer maturity fruit was $17.70 \mathrm{mg}$ and $20.26 \mathrm{mg}$ at the botanical maturity.

The statistical analysis showed probative difference in vitamin $\mathrm{C}$ content between the two monitored years and four variants of different maturity (Table 3, Figure 6). Insignificant differences were found between varieties and repetitions.

\section{Conclusions}

The paper examined the comparison of the vitamin $C$ contents in different varieties and demonstrated the amount of this vitamin in various ripeness variants of tomatoes. The results confirmed that the maturation of fruits significantly increase the amount of vitamin C. The significant difference in the content of vitamin $C$ has not been established between varieties and repetitions. The production of vitamin $C$ is affected by fruit maturity, seasons, soil and agricultural engineering. 


\section{Acknowledgement}

This paper was supported by grant VEGA 1/0507/16

\section{References}

DORAIS, M. - EHRET, D. L. - PAPADOPOULOS, A. P. 2008. Tomato (Solanum lycopersicum) health components: from the seed to the consumer. In Phytochem Rev, no. 7, pp. 231-250. DOI 10.1007/ s11101-007-9085-x

JEDLIČKA, J. 2012. Ovocie a zelenina pri prevencii a liečbe ochorení ludí (Fruit and vegetables in the prevention and treatment of human diseases). Nitra : SPU, 190 s. ISBN 978-80-552-0859-6.

KERESTEŠ, J. a i. 2011. Zdravie a výživa ludí. Bratislava : CAD Press, 2011, 1037 p. ISBN 978-80-88969-57-0.

KADER, A. A. 1999. Fruit maturity ripening and quality relationships Proceedings International Symposium on Effect of Pre and Postharvest Factors on Storage of Fruits. In Acta Horticulture, 485, pp. 203-208.

KOPEC, K. 1998. Tabulky nutričních hodnot ovoce a zeleniny (Tables of nutritional values of fruits and vegetables). Praha : ÚZPI, $72 \mathrm{~s}$. ISBN 80-96153-649.

KOPEC, K. 2010. Zelenina ve výživě člověka (Vegetables in human nutrition). Praha: Grada Publishing, a.s., 168 s. ISBN 978-247-2845-2.

MERAVÁ, E. a i. 2015. Zelenina - situačné a výhl'adová správa k 31.12 2014 (Vegetables - Situation and Outlook Report to 31. 12. 2014). Bratislava : Ministerstvo pôdohospodárstva a rozvoja vidieka SR Výskumný ústav ekonomiky polnohospodárstva a potravinárstva, 49 s. ISSN 1338-8010.
STAN, M. - SORAN, M. L. - MARUTOIU, C. 2014. Extraction and HPLC Determination of the Ascorbic Acid Content of Three Indigenous Spice Plants. In Journal of Analytical Chemistry, vol. 69, no. 10, pp. 998-1002. https://doi.org/10.1134/S106193481410013X RAHMAN M.M. - MONIRUZZAMAN, M. - AHMAD, M. R. - SARKERA, B. C. - ALAM, M. K. 2016. Maturity stages affect the postharvest quality and shelf-life of fruits of strawberry genotypes growing in subtropical regions. In Journal of the Saudi Society of Agricultural Sciences, vol. 15, no. 1, pp. 28-37.

ROZBORILOVÁ, E. a i. 2016. Definitívne údaje o úrode polnohospodárskych plodín a zeleniny v SR za rok 2015 (Final yields data of agricultural crops and vegetables in Slovakia in 2015). Kód 081016, č. 850-0063/2016 Štatistický úrad Slovenskej republiky, ISBN 978-80-9121-494-3.

TOOR, R. K. - SAVAGE, G. P. 2004. Antioxidant activity in different fractions of tomatoes. In Food Research International, no. 38, pp. 487-494.

UHER, A. - KÓŇA, J. - VALŠíKOVÁ, M. - ANDREJIOVÁ, A. 2009. Zeleninárstvo - polné pestovanie (Vegetables - growing in the field). Nitra : SPU, 212 s. ISBN 978-80-552-0199-3.

VALŠíKOVÁ, M. a i. 1996. Produkčné systémy vybraných druhov zelenín (Production systems of selected vegetable species). Bratislava : SPPK, Nové Zámky : VÚZ, 201 s.

VALŠíKOVÁ, M. - PAULEN, O. 2013. Study of Capsicum diversity and quality. Praha : Profi Press. ISBN 978-80-86726-56-4. 